\title{
Effect of (+)-usnic acid on the shot-hole borer (Xyleborus fornicatus Eichh.) of tea
}

\author{
Kamila Sahib, N. Sepalika Kularatne, Savitri Kumar and Veranja Karunaratne* \\ Department of Chemistry, Faculty of Science, University of Peradeniya, Peradeniya.
}

Revised: 24 June 2008 ; Accepted: 11 August 2008

The shot-hole borer (SHB), Xyleborus fornicatus Eichh. is a small, wood boring ambrosia beetle belonging to the family Scolytidae. SHB is considered as the most serious pest of Tea (Camellia sinensis var. assimica) in Sri Lanka and is of greater economic importance than the other teainfesting insects and mite pests put together ${ }^{1}$. Certain tea cultivars show a higher degree of susceptibility to this pest. The use of utilization of persistent insecticides such as DDT, dieldrin, aldrin and telodrin to control SHB has caused serious secondary pest outbreaks ${ }^{2}$. This paper deals with the potent activity of (+)-usnic acid against X. fornicatus.

(+)-usnic acid was isolated from an Usnea sp. collected from the surface of a rotting Acacia decurrans tree in Ambewela, Sri Lanka ${ }^{3,4}$. The control medium was prepared using sucrose $(1.409 \mathrm{~g})$, casein $(0.929 \mathrm{~g})$, yeast $(0.929 \mathrm{~g})$ Wesson salt $(0.118 \mathrm{~g})$, agar $(3.479 \mathrm{~g})$, cellulose $(17.0 \mathrm{~g})$ and distilled water $(75 \mathrm{ml})^{5,6,7} .(+)$-Usnic acid was dissolved in acetone $(2 \mathrm{ml})$ and then distilled water was added to yield 50, 75 and100 ppm solutions. Solutions were incorporated into cellulose powder and mixed with the rest of the medium and ground thoroughly to a fine pulp.

An equal quantity of each of the diet mixtures and the control was dispensed into six separate sets of boiling tubes. A test tube was placed upright in the center of each boiling tube so that there was a thin layer of the medium between the walls of the inner test tube and the outer boiling tube, mimicking an artificial tea stem inside the tubes ${ }^{7}$. Six replicates (control and tests) were prepared and the boiling tubes were sealed with cotton plugs and aluminum foils. The tubes were autoclaved at $1.2 \mathrm{~kg} / \mathrm{cm}^{2}$ at $120^{\circ} \mathrm{C}$ for $15 \mathrm{~min}$., allowed to cool to room temperature, and kept in a refrigerator for 3-4 days before use. TLC was used to confirm that no decomposition had taken place during autoclaving.

Healthy adult females of $X$. fornicatus were collected from beetle infested tea bushes (clone TRI 2025) at the Tea Research Institute sub-station in Hantane. The beetles were surface sterilized with $0.1 \% \mathrm{NaOCl}(4-5 \mathrm{~min})^{7}$. Two sterilized adult female beetles were introduced into each culture tube. The tubes were kept at $26 \pm 2^{\circ} \mathrm{C}$ in darkness $(24 \mathrm{~h})$. Daily observations upto 60 days were made from 11.45 a.m. to 1.00 p.m. during which the beetles are most active.

$(+)$-Usnic acid has been found to show remarkable antibiotic, antitumour, antimutagenic, plant growth inhibitory and enzyme inhibitory activities ${ }^{8}$. In a previous study, we reported the antitermite and antifungal activity of (+)-usnic acid. ${ }^{9}$<smiles>CC(=O)C1=C(O)C=C2c3c(c(O)c(C)c(O)c3C(C)=O)OC2(C)C1=O</smiles>

(+)-Usnic acid

Growth and development of SHB is adversely affected by the presence of (+)-usnic acid in the artificial dietary media (Table 1). At 75 and 100 ppm, only 10 and 4 mother beetles produced progeny, respectively. The galleries constructed in the test media containing (+)-usnic acid, were of an irregular shape compared to the control.

The late appearance of the fungus Monacrosporium ambrosium (which maintains a symbiotic relationship 
Table 1: Average time (days) taken for development of galleries, M. ambrosium and the various stages in the life cycle of $X$. fornicatus $\#$ in the test media

\begin{tabular}{lcccc}
\hline Observation & (a) & (b) & (c) & (d) \\
\hline Eggs & $6-9$ & $7-10$ & $9-14$ & $13-15$ \\
Larvae & $11-14$ & $12-14$ & $15-17$ & $17-20$ \\
Immature beetles & $20-24$ & $22-27$ & $18-23$ & $27-31$ \\
Mature beetles & $24-27$ & $26-30$ & $26-31$ & $31-34$ \\
Number of emerging & $90 \mathrm{~F}$ & $65 \mathrm{~F}$ & $14 \mathrm{~F}$ & $6 \mathrm{~F}$ \\
beetles & $17 \mathrm{M}$ & $14 \mathrm{M}$ & $2 \mathrm{M}$ & $1 \mathrm{M}$ \\
\hline
\end{tabular}

(a) Control; (b), (c), (d): 50, 75,100 ppm (+)-usnic acid, respectively. F (Female); M (Male).

with the beetle), correlated with the increase in the concentration of (+)-usnic acid. Interestingly, a separate recent study showed the antifungal activity of caffeine in tea on M. ambrosium ${ }^{7}$ and we had previously reported potent activity of $(+)$-usnic acid against several fungal species including M. ambrosium ${ }^{4}$. Thus, it is likely that the antifungal activity of (+)-usnic acid against M. ambrosium is a key factor in the retardation of the growth and development of the beetle. The number of adults that emerged from the test media containing 75 and $100 \mathrm{ppm}$ of (+)-usnic acid were 16 and 7 respectively which were relatively small compared to the control in which the number was 107. Prior to this study, there had been only one report of the insecticidal activity of usnic acid which was against the polyphagous herbivorous insect Spodoptera littoralis ${ }^{10}$.

\section{References}

1. Wickramasinghe R.L.(1978). The biochemical relationship of pests and pathogens to tea. Monographs of Tea Products in Sri Lanka 7:39-43.

2. Cranham J.E. (1966). Tea Pests and their Control. Annual Reviews of Entomology 11: 491-514.

3. Williams D.E., Bombuwela K., Lobkovsky E., De Silva E.D., Karunaratne V., Allen T., Clardy J. \& Andersen
R.J. (1998). Ambewalamides A and B, Antineoplastic Epidithiapiperazinediones isolated from the lichen Usnea sp. Tetrahedron Letters 39: 9579-9582.

4. Bombuwela K. (2001). Isolation and bioactivity studies of lichen substances from Sri Lankan lichens. Ph.D. Thesis, Department of Chemistry, University of Peradeniya.

5. Sivapalan P. (1976). Control of Shot Hole Borer of Tea (Xyleborous fornicatus Eichh.), Final Report on Research Conducted Under a Grant Authorised by U.S. Public Law 480, TRI, Talawakelle.

6. Sivapalan P. \& Sivanandarajah V. (1977). Diets for rearing the ambrosia beetle of tea, Xyleborus fornicatus (Coleoptera: Scolytidae) in vitro. Entomologia Experimentalis et Applicata 21: 1-8.

7. Hewapathiranage P., Karunaratne W.S. \& Kumar N.S. (1999). Effect of caffeine on shot-hole borer beetle (Xyleborus fornicatus) of tea (Camellia sinensis). Phytochemistry 51: 35-41.

8. Huneck S. \& Yoshimura I. (1996). Identification of Lichen substances. Springer-Verlag, Berlin.

9. Bombuwela K., Subramanium V., De Silva K.S., Adikaram N.K.B. \& Herath H.M.T.B. (2000). Antitermite and antifungal activity of usnic acid and atranorin. Ceylon Journal of Science (Physical Sciences) 6: 8-12.

10. Emmerich R., Giez I., Lange O.L. \& Proksch P. (1993). Toxicity and antifeedant activity of lichen compounds against the polyphagous herbivorous insect Spodoptera littoralis. Phytochemistry 33:1389-1394. 